\title{
EFEKTIVITAS PENGGUNAAN MgSO4 SEBAGAI TOKOLITIK PADA ANCAMAN PERSALINAN PREMATUR DI RSUP DR. WAHIDIN SUDIROHUSODO
}

\author{
Nurhikma A. ${ }^{1}$, Elly Wahyudin ${ }^{1}$, Nasruddin AM $^{2}$ \\ ${ }^{1}$ Fakultas Farmasi, Universitas Hasanuddin, Makassar \\ ${ }^{2}$ Rumah Sakit Ibnu Sina, Makassar
}

Kata Kunci

Persalinan Prematur, Kontraksi, $\mathrm{MgSO}_{4}$

\begin{abstract}
ABSTRAK
Penelitian ini dilakukan di Rumah Sakit Dr. Wahidin Sudirohusodo Makassar. Rumah Sakit Umum Daerah Labuang Baji, RSIA Sitti Khadijah, dan Klinik Sitti Khadijah Makassar dari Mei hingga Juli 2017 bertujuan menguji efektifitas penggunaan obat MgSO4 sebagai tokolitik pada pasien dengan ancaman persalinan prematur di Makassar. Terdapat 32 pasien yang terdaftar dalam penelitian. Jenis penelitian ini merupakan penelitian observasional dengan mengikuti rancangan deskriptif analitik dan pengambilan data secara prospektif. Hasil penelitian ini adalah dari 32 pasien yang mendapat terapi MgSO4, 2 orang yang berhasil menunda persalinan prematur dalam waktu $2 \times 24$ jam pada pemberian terapi ke 2 tanpa kontraksi, 21 pasien yang berhasil menunda persalinan prematur dalam waktu $2 \times 24$ jam pada pemberian terapi ke 3 tanpa kontraksi, 6 pasien yang berhasil menunda persalinan dengan penurunan kontraksi tersisa $1 \times 10$ menit (15-20 detik) dan 5 pasien yang berhasil menunda persalinan dengan penurunan kontraksi tersisa 1x10 menit (10-15 detik) masing-masing pada pemberian terapi ke 3. Dari hasil tersebut dapat disimpulkan bahwa, efektifitas MgSO4 dalam menunda persalinan prematur dalam waktu 2x24 jam adalah sebesar $71.87 \%$.
\end{abstract}

\section{PENDAHULUAN}

Bayi yang lahir prematur (sebelum minggu 37 kehamilan) sering mengalami morbiditas dan kebutuhan yang sangat signifikan di unit perawatan intensif neonatal (1). Apalagi ada risiko neurologis jangka panjang yang signifikan, morbiditas dalam hal ini korban selamat (2). Semakin dini kelahiran bayi semakin besar risikonya, terutama saat kelahiran terjadi sebelum minggu 32. Orangtua dikhawatirkan tertekan saat bayinya lahir prematur. Oleh karena itu, pencegahan kelahiran prematur tetap menjadi prioritas penting (3).

WHO tahun 2015 mendefinisikan preterm sebagai usia kehamilan yang kurang dari 37 minggu lengkap (259 hari) sejak hari pertama haid terakhir (4). Estimasi yang reliabel untuk angka kelahiran prematur tidak tersedia untuk Indonesia. Meskipun demikian, pada tahun 2012 WHO mencatat bahwa, angka kejadian kelahiran prematur di Indonesia pada tahun 2010 adalah 15,5 per 100 kelahiran hidup dan menempatkan Indonesia diposisi ke-9 tertinggi dari 184 negara (5). Angka ini cukup besar jika dibandingkan dengan negara Belarus yang menempati urutan terakhir dengan jumlah kelahiran prematur sebesar 4,1 per 100 kelahiran hidup.

Bayi Berat Lahir Rendah, atau BBLR adalah bayi lahir dengan berat badan 1.500 g sampai kurang dari 2500 gram. Menurut World Health Organization (WHO), diantara 130 juta bayi yang lahir setiap tahun di seluruh dunia, 8 juta meninggal sebelum mereka mencapai waktu kelahirannya. Di Amerika Serikat $17 \%$ sampai $34 \%$ dari kematian bayi dikaitkan dengan prematuritas (5).

Masalah BBLR merupakan masalah utama di negara berkembang termasuk Indonesia. Bayi lahir berat rendah merupakan penyebab terjadinya peningkatan angka mortalitas dan morbiditas pada bayi, penyebab utamanya adalah prematuritas (6).

Berdasarkan hal tersebut perlu dilakukan upaya-upaya dalam mencegah kejadian kelahiran secara prematur dengan cara menghambat kelahiran sebelum 37 minggu dengan menggunakan obat-obat tokolitik. Terapi tokolitik merupakan terapi yang digunakan dalam menghambat kelahiran prematur dengan cara menghambat kontraksi uterus sehingga dapat memperpanjang masa kehamilan dan mengurangi komplikasi neonatal (7).

Berdasarkan atas landasan teori-teori di atas, maka peneliti merasa perlu dilakukan penelitian tentang efektifitas penggunaan $\mathrm{MgSO} 4$ sebagai tokolitik pada ancaman persalinan prematur di Makassar.

\section{METODE PENELITIAN}

Jenis penelitian ini merupakan penelitian penelitian observasional noneksperimen dengan analisis deskriptif. Waktu penelitian dilaksanakan pada periode bulan April sampai mencukupi sampel dan lokasi penelitian di beberapa RSUP Dr. Wahidin Sudirohusodo Makassar, RSUD Labuang Baji, RSIA Sitti Khadijah, dan Klinik Sitti Khadijah Makassar.

Bahan penelitian untuk mengevaluasi efektivitas penggunaan MgSO4 pada pasien dengan resiko kelahiran prematur yaitu regimen terapi (dosis pemberian dan aturan pemakaian), serta kondisi klinis pasien. Populasi sampel adalah pasien dengan ancaman partus preterm yang mendapatkan terapi $\mathrm{MgSO}_{4}$. Sampel adalah 
pasien yang dirawat inap di RSUP Dr. Wahidin Sudirohusodo Makassar, RSUD Labuang Baji, RSIA Sitti Khadijah, dan Klinik Sitti Khadijah Makassar. Besar sampel (n) ditentukan dengan menggunakan rumus Slovin.

Penetapan sampel akan dievaluasi dengan kriteria inklusi: 1) Pasien ibu hamil yang terancam bersalin secara prematur yang mengalami kontraksi; 2) Pasien yang tidak memiliki riwayat infeksi genital; 3) Pasien dengan kehamilan tunggal; 4) Pasien dengan usia ibu 20 - 40 tahun. Kriteria eksklusi: 1) Pasien yang tidak bersedia menjadi sampel penelitian; 2) Pasien dengan kehamilan ganda; 3) Pasien yang tidak mempunyai riwayat penyakit jantung; 4) Pasien yang tidak mempunyai riwayat penyakit ginjal.

Obat yang akan dievaluasi adalah obat yang digunakan pada terapi tokolitik yaitu MgSO4 yang digunakan oleh pasien dengan ancaman partus preterm di RSUP Dr. Wahidin Sudirohusodo Makassar, RSUD Labuang Baji, RSIA Sitti Khadijah, dan Klinik Sitti Khadijah Makassar.

Pengambilan data dilakukan dengan subyek penelitian yang memenuhi syarat penerimaan sampel dilakukan pengacakan di RSUP Dr. Wahidin Sudirohusudo, ruang rawat inap di RSIA Sitti Khadijah, ruang baji gau RSUD Labuang Baji, dan Klinik Sitti Khadijah Makassar. Efektifitas terapi tokolitik akan dinilai dengan keberhasilan menunda persalinan selama $2 \mathrm{x}$ 24 jam. Jika tokolitik berhasil, pasien dirawat sampai 2 hari bebas kontraksi.

\section{HASIL DAN PEMBAHASAN}

Pada tabel 1 menunjukkan jumlah responden yang berusia 20 - 25 tahun sebanyak 12 orang dengan persentase $37.5 \%$, usia 25 - 30 tahun sebanyak 8 orang dengan persentase $25 \%$, usia 30 - 35 tahun sebanyak 7 orang dengan persentase $21.87 \%$ dan usia 35 - 40 tahun sebanyak 5 orang dengan persentase $15.62 \%$. Gravidarum nullipara sebanyak 13 orang dengan persentase $40.62 \%$, primipara sebanyak 12 orang dengan persentase $37.5 \%$, dan multipara sebanyak 7 orang dengan persentase $21.87 \%$. Riwayat abortus pasien menunjukkan jumlah responden tanpa riwayat abortus sebanyak 19 orang dengan persentase $59.37 \%$, sedangkan pasien dengan riwayat abortus sebanyak 13 orang dengan persentase $40.62 \%$. Riwayat persalinan prematur pada tabel menunjukkan sebanyak 25 orang dengan persentase $78.12 \%$ pasien yang tidak memiliki riwayat partus prematur, dan 7 orang dengan persentase $21.87 \%$ pasien yang memiliki riwayat partus prematur. Berat badan $<50 \mathrm{~kg}$ berjumlah 11 orang dengan persentase $34.37 \%$ dan $\geq 50 \mathrm{~kg}$ berjumlah 21 orang dengan persentase $65.62 \%$. Kejadian persalinan prematur hampir 3 kali lebih tinggi pada ibu yang berat badannya kurang $50 \mathrm{~kg}$ pada saat hamil. Tingkat pendidikan ditunjukkan tabel dengan pendidikan terakhir SD sebanyak 17 orang dengan persentase $53.12 \%$, pendidikan terakhir SMP sebanyak 6 orang dengan persentase 18.75\%, SMA sebanyak 5 orang dengan persentase $15.62 \%$, diploma sebanyak 2 orang dengan persentase $6.25 \%$ dan Strata satu sebanyak 2 orang dengan persentase $6.25 \%$.

Dari 32 pasien yang mendapat terapi MgSO4, sebanyak 2 orang $(6.25 \%)$ yang berhasil menunda persalinan prematur dalam waktu $2 \times 24$ jam pada pemberian terapi ke 2 tanpa kontraksi. sebanyak 21 orang (65.62\%) yang berhasil menunda persalinan prematur dalam waktu $2 \times 24$ jam pada pemberian terapi ke 3 tanpa kontraksi. Sedangkan 6 orang (18.75\%) yang berhasil menurunkan kontraksi tersisa $1 \times 10$ menit (20-25 detik) dan 5 pasien (15.62\%) yang berhasil menurunkan kontraksi tersisa $1 \times 10$ menit (10-15 detik) masing-masing setelah pemberian terapi ke 3 . Dari hasil tersebut dapat disimpulkan bahwa, efektifitas MgSO4 dalam menunda persalinan prematur dalam waktu $2 \times 24$ jam tanpa kontraksi adalah sebesar $71.87 \%$.

\begin{tabular}{|c|c|c|}
\hline \multirow{2}{*}{$\begin{array}{l}\text { Karakteristik } \\
\text { Pasien }\end{array}$} & \multirow[b]{2}{*}{$\mathrm{n}$} & \multirow[b]{2}{*}{$f(\%)$} \\
\hline & & \\
\hline \multicolumn{3}{|l|}{ Usia ibu (tahun) } \\
\hline $20-25$ tahun & 12 & 37.5 \\
\hline $25-30$ tahun & 8 & 25 \\
\hline $30-35$ tahun & 7 & 21.87 \\
\hline $35-40$ tahun & 5 & 15.62 \\
\hline \multicolumn{3}{|l|}{ Gravidarum } \\
\hline Nulliparra & 13 & 40.62 \\
\hline Primipara & 12 & 37.5 \\
\hline Multipara & 7 & 21.87 \\
\hline \multicolumn{3}{|l|}{ Riwayat abortus } \\
\hline Ya & 13 & 40.62 \\
\hline Tidak & 19 & 59.37 \\
\hline \multicolumn{3}{|l|}{$\begin{array}{l}\text { Riwayat } \\
\text { persalinan } \\
\text { prematur }\end{array}$} \\
\hline Ya & 7 & 21.87 \\
\hline Tidak & 25 & 78.12 \\
\hline \multicolumn{3}{|l|}{$\begin{array}{l}\text { Berat badan } \\
(\mathrm{kg})\end{array}$} \\
\hline$<50$ & 11 & 34.37 \\
\hline$\geq 50$ & 21 & 65.62 \\
\hline \multicolumn{3}{|l|}{ Pendidikan } \\
\hline SD & 17 & 53.12 \\
\hline SMP & 6 & 18.75 \\
\hline SMA & 5 & 15.62 \\
\hline DIPLOMA & 2 & 6.25 \\
\hline S1 & 2 & 6.25 \\
\hline Jumlah & 32 & \\
\hline
\end{tabular}

Tabel 2 Menunjukkan jumlah pasien dengan skala nyeri sebelum pemberian terapi yaitu sebanyak 12 orang (37.5\%) dengan skala nyeri 5, 9 orang (28.12\%) dengan skala nyeri 4 , 6 orang (18.75\%) dengan skala nyeri 3, dan 5 orang (15.62\%) dengan skala nyeri 2 . Sedangkan setelah pemberian terapi pertama, terdapat penurunan skala nyeri yaitu sebanyak 10 orang $(31.25 \%)$ dengan skala nyeri 5,6 orang $(18.75 \%)$ dengan skala nyeri 4, 5 orang (15.62\%) dengan skala nyeri 3 , 4 orang $(12.5 \%)$ dengan skala nyeri 2,7 orang $(21.87 \%)$ dengan skala nyeri 1 . Kemudian pemberian terapi ke 2 menunjukkan sebanyak 4 orang (6.25\%) dengan skala nyeri 3,9 orang $(28.12 \%)$ dengan skala nyeri 2,17 orang $(53.12 \%)$ dengan skala nyeri 1 dan 2 orang (6.25\%) dengan skala nyeri 0 . Sedangkan setelah pemberian terapi ke tiga menunjukkan penurunan skala nyeri yang signifikan yaitu sebanyak 2 orang (6.25\%) dengan skala nyeri 2, 9 orang $(28.12 \%)$ dengan skala nyeri 1 dan 21 orang $(65.62 \%)$ dengan skala nyeri 0 . Dengan melihat data, dapat disimpulkan bahwa efektifitas MgSO4 terhadap penurunan skala nyeri adalah sebanyak $71.87 \%$ dapat mengurangi nyeri pada pasien. 
Tabel 2. Pengaruh pemberian terapi MgSO4 Pre dan Post terhadap skala nyeri

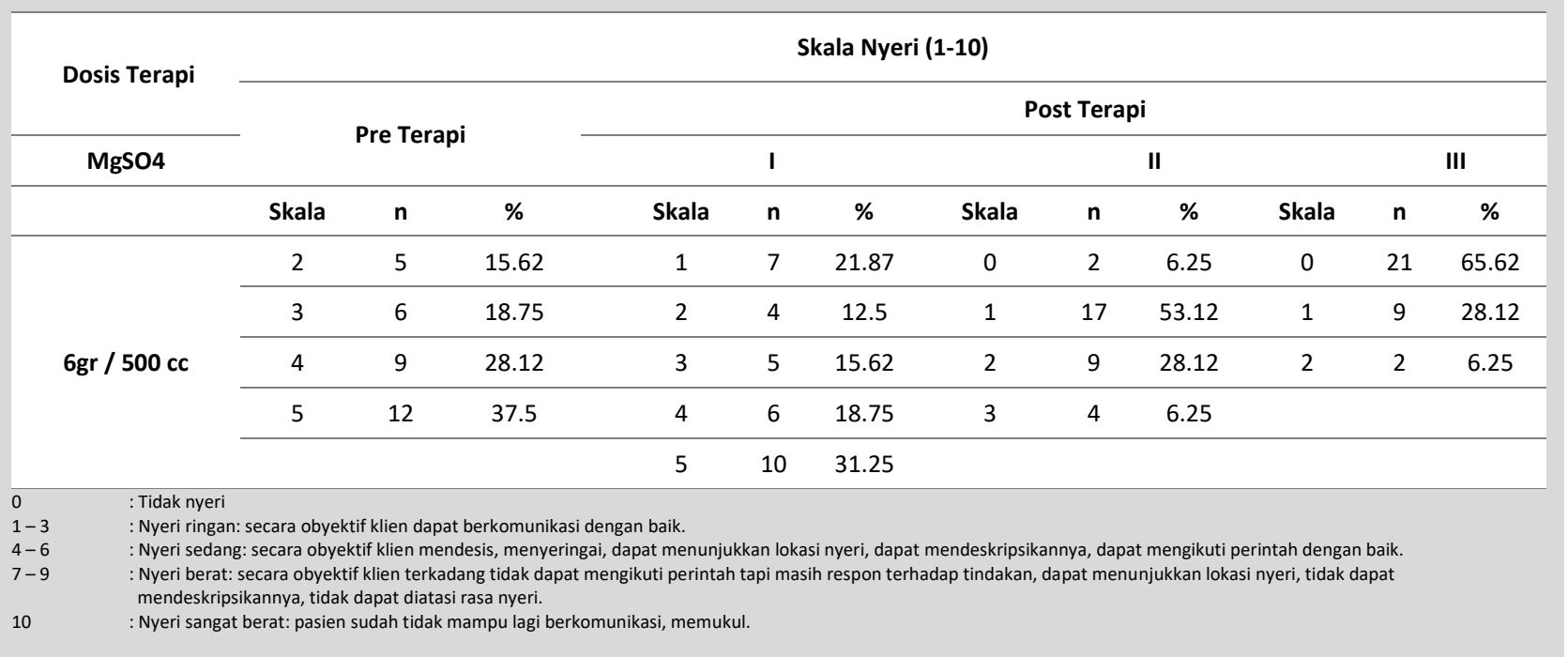

Penelitian ini dilakukan dengan analisis deskriptif, sebanyak 32 sampel yang ditentukan berdasarkan rumus Slovin. Dilakukan di ruang perawatan obgyn Gedung Lontara 4 bawah di RSUP Dr. Wahidin Sudirohusodo Makassar, ruang rawat inap Baji RSUD Labuang Baji, RSIA Sitti Khadijah, dan Klinik Sitti Khadijah Makassar. Pengambilan data penelitian dilakukan pada pasien yang didiagnosis terancam bersalin prematur dengan usia kehamilan $<37$ weeks yang dirawat periode bulan Mei - Juli 2016. Sampel adalah pasien ibu hamil yang masuk kategori inklusi yang dirawat di Lontara 4 bawah RSUP Dr. Wahidin Sudirohusodo sebanyak 13, ruang rawat inap RSUD Labuang Baji sebanyak 6, RSIA Sitti Khadijah sebanyak 9, dan Klinik Sitti Khadijah Makassar sebanyak 4 orang dengan jumlah sampel 32 pasien.

Penelitian dilakukan dengan cara pengisian inform consent oleh pasien sebagai kesediaan pasien menjadi sampel penelitian. Observasi pasien secara langsung dan wawancara dengan pasien secara non formal. Selanjutnya dilakukan pencatatan status pasien. Jenis data yang dikumpulkan selama penelitian meliputi karakteristik pasien (nama, usia, usia kehamilan), kondisi klinis pasien (hasil laboratorium, tanda-tanda vital). Data yang diperoleh selanjutnya diolah dan disajikan dalam bentuk tabel yang disertai dengan penjelasan.

Ibu yang muda yaitu yang berusia $\leq 20$ tahun atau yang berusia 35 tahun terbukti memiliki insiden persalinan prematur yang lebih tinggi. Pada kelahiran anak yang kedua, ibu yang berusia antara 15 dan 20 tahun berisiko tiga kali lebih tinggi mengalami kelahiran yang sangat prematur dan bayi lahir mati dibandingkan ibu yang berusia 20 - 29 tahun. Menurut Astolfi dan Zonta tahun 2002 mendapatkan 64\% peningkatan kejadian persalinan prematur pada populasi wanita Italia yang berusia 35 tahun atau lebih, terutama pada kehamilan pertama (8).

Sebuah penelitian di Thailand menunjukkan bahwa perempuan yang berumur $\leq 20$ tahun memiliki resiko lebih besar untuk terjadinya persalinan prematur dibandingkan perempuan berumur $>20$ tahun. (9)

Kehamilan usia muda lebih memungkinkan mengalami penyulit pada masa kehamilan dan persalinan yaitu karena wanita muda sering memiliki pengetahuan yang terbatas tentang kehamilan atau kurangnya informasi dalam mengakses sistem pelayanan kesehatan. Pada usia ini juga belum cukup dicapainya kematangan fisik, mental dan fungsi organ reproduksi dari calon ibu. Golongan primigravida muda (kehamilan pertama) dimasukkan dalam golongan risiko tinggi, karena angka kesakitan dan angka kematian ibu dan bayi pada kehamilan remaja $2-4 \mathrm{x}$ lebih tinggi dibandingkan dengan usia reproduksi.

Jumlah gravidarum merupakan salah satu faktor predisposisi terjadinya kelahiran prematur karena jumlah paritas dapat mempengaruhi keadaan kesehatan ibu dalam kehamilan. Menurut Krisnadi, (8) menyatakan bahwa penyebab partus prematur antara lain karena faktor maternal yang salah satunya adalah faktor paritas. Berdasarkan penelitian menyatakan bahwa paritas dengan dengan kejadian partus prematur mempunyai hubungan yang bermakna, dimana pada wanita yang paritas lebih dari 3 ada kecenderungan mempunyai risiko sebesar 4 kali lebih besar untuk melahirkan bayi prematur bila dibandingkan dengan wanita yang paritasnya kurang dari 3.

Semakin tinggi paritas semakin tinggi pula risiko terjadinya persalinan preterm. Ibu dengan paritas rendah cenderung bayi yang dilahirkannya tidak matur atau ada komplikasi karena merupakan pengalaman pertama terhadap kemampuan alat reproduksi ibu dan kemungkinan akan timbul penyakit dalam kehamilan dan persalinan (10)

Paritas tinggi merupakan paritas rawan karena banyak kejadian obstetric patologi yang bersumber pada paritas tinggi, antara lain ; preeklampsi, perdarahan antenatal sampai atonia uteri. Hal ini disebabkan pada ibu yang lebih dari satu kali mengalami kehamilan dan persalinan fungsi reproduksi telah mengalami penurunan (10).

Paritas tinggi merupakan paritas rawan karena banyak kejadian obstetri patologi yang bersumber pada paritas tinggi, antara lain preeklampsi, perdarahan antenatal sampai atonia uteri. Hal ini disebabkan pada ibu yang lebih dari satu kali mengalami kehamilan dan persalinan fungsi reproduksi telah mengalami penurunan (10)

Sebuah studi di Prancis menunjukkan bahwa aborsi dapat meningkatkan resiko kelahiran prematur pada kehamilan berikutnya sebanyak $70 \%$. Hal ini disebabkan karena aborsi dapat merusak dinding rahim. Dinding rahim merupakan tempat melekatnya plasenta, salah satu fungsi plasenta adalah tempat pembuatan hormon-hormon. Khususnya hormone korionik gonadotropin, somato mammotropin (placental lactogen), estrogen dan progesteron, dan jika tidak dapat bekerja dengan baik, maka pembuatan hormon dapat terganggu. Jika produksi hormon progesterone menurun maka dapat menyebabkan kontraksi pada rahim yang memicu kelahiran prematur. Abortus juga dapat berdampak perdarahan sampai menimbulkan shock dan gangguan neurologis/ syaraf dikemudian hari. Perdarahan dapat 
mengakibatkan infeksi alat reproduksi dan penipisan dinding uterus karena kuretasi yang dilakukan secara tidak steril. (11).

Riwayat persalinan prematur sebelumnya merupakan penanda risiko paling kuat dan paling penting.Berdasarkan data Health Technology Assessment Indonesia tahun 2010 bahwa insiden terjadinya persalinan prematur selanjutnya setelah $1 x$ persalinan prematur meningkat hingga $14,3 \%$ dan setelah 2x persalinan prematur meningkat hingga $28 \%$. Wanita yang mengalami persalinan prematur memiliki risiko untuk mengalaminya kembali pada kehamilan selanjutnya (12).

Risiko kelahiran bayi prematur meningkat pada wanita yang memiliki riwayat melahirkan prematur sebelumnya. Bahkan, studi menunjukkan wanita yang melahirkan prematur berada pada tingkat peluang 30-50 persen lebih tinggi untuk mengalami kelahiran bayi prematur di kehamilan berikutnya.

Riwayat melahirkan prematur merupakan faktor risiko terkuat untuk kelahiran prematur berulang dan kekambuhan sering terjadi pada usia yang sama, dengan sekitar 70 persen persalinan dini terjadi dalam waktu dua minggu usia kehamilan dari kelahiran prematur pertama. Kelahiran bayi prematur iatrogenik (disebabkan oleh perawatan dokter terhadap suatu penyakit atau suatu kondisi pasien) menyumbang lebih dari 30 persen dari seluruh kejadian kelahiran prematur. Tingkat kelahiran bayi prematur terus meningkat di banyak negara di seluruh dunia karena peningkatan tingkat kelahiran prematur yang ditunjukkan.

Berat badan berlebihan juga menjadi faktor terjadinya persalinan prematur. Hampir setengah dari wanita mengalami kenaikan berat badan terlalu banyak selama kehamilan, 21 persen tidak mendapatkan jumlah yang disarankan, menurut sebuah studi. Bukti menunjukkan bahwa berat badan pra-kehamilan yang rendah dikaitkan dengan peningkatan risiko kelahiran prematur.

Ibu hamil yang obesitas juga berada pada peningkatan risiko komplikasi tertentu selama kehamilan, masa persalinan dan kelahiran bayi, dan periode post-partum. Risiko termasuk peningkatan risiko malformasi bayi, termasuk cacat tabung saraf (spina bifida), distosia bahu, dan trauma lahir lainnya, termasuk endometritis dan infeksi luka operasi caesar, dibandingkan dengan wanita non-obesitas.

Obesitas pra-kehamilan memiliki peran dalam faktor risiko kelahiran prematur dengan meningkatkan risiko ketuban pecah dini (PPROM). Risiko kelahiran prematur spontan pada ibu obesitas saat kurang dari 37 minggu kehamilan, tanpa PPROM berkurang: 6,2\% dibandingkan $11,2 \%$ pada ibu nonobesitas.

Faktor tingkat pendidikan wanita juga signifikan mempengaruhi kejadian kelahiran prematur di mana wanita berpendidikan lebih rendah cenderung 1,077 kali lebih besar untuk mengalami kelahiran bayi prematur dibandingkan dengan ibu yang berpendidikan lebih tinggi. Meskipun nilai odds ratio yang dihasilkan tidak terlalu besar perbedaannya antara ibu yang berpendidikan tinggi dan rendah, namun angka tersebut signifikan pada taraf signifikansi 5\% (13).

Latar belakang pendidikan ibu yang rendah menyulitkan berlangsungnya suatu penyuluhan kesehatan terhadap ibu karena mereka kurang menyadari pentingnya informasi informasi tentang kesehatan ibu hamil, sehingga mereka tidak mengetahui cara pemeliharaan kesehatan terutama pada saat hamil (14).

Tinggi rendahnya tingkat pendidikan ibu erat kaitannya dengan tingkat pengertian terhadap perawatan kesehatan, higiene, dan perlunya pemeriksaan kehamilan. Rendahnya tingkat pendidikan dan kurangnya informasi yang menyebabkan masih banyaknya ibu-ibu yang kurang menyadari pentingnya pemeriksaan kehamilan menyebabkan tidak terdeteksinya faktor-faktor risiko tinggi yang mungkin dialami oleh mereka. Risiko ini baru diketahui pada saat persalinan yang sering kali karena kasusnya sudah terlambat sehingga dapat membawa akibat fatal. Sebagai akibat dari kurangnya kesadaran akan pentingnya pemeriksaan kehamilan dapat berdampak pada terjadinya persalinan prematur karena tidak terdeteksinya berbagai masalah kesehatan pada ibu. Dengan demikian, faktor pendidikan ibu merupakan salah satu determinan penting yang mempengaruhi kejadian kelahiran prematur (15).

Kontraksi dari persalinan yang sesungguhnya mula-mula berlangsung sekitar 30 detik, dan terjadi secara teratur kirakira 15 sampai 20 menit. Selama kontraksi, rahim dapat dirasakan menjadi keras dan sakit, baik hanya di daerah tertentu punggung, atau bersama dengan proses persalinan, menyebar ke perut. Kenyataannya, semakin berkurang sakit punggung, persalinan semakin efisien. Rasa sakit dimulai seperti sedikit tertusuk, dan mencapai puncak, kemudian menghilang seluruhnya. Dengan berkembangnya proses persalinan, lamanya kontraksi meningkat dari 30 detik menjadi 90 detik, jarak waktu antara setiap kontraksi berkurang dari 20 menit menjadi 3 atau 5 menit, dan intensitas kontraksi meningkat

Sebuah penelitian pada tahun 2010, telah diambil sampel secara acak sebanyak $90 \%$, atau 29 dari 33 jumlah total perempuan menunda persalinan mereka setelah diberikan terapi MgSO4. Magnesium sulfat bekerja pada kalsium yang bergantung pada voltase saluran untuk menghalangi masuknya kalsium, dan untuk menghambat rantai miosin yang bergantung pada kalsium kinase fosforilasi (15).

Glock and Morales mengevaluasi pemberian MgSO4 secara random sebanyak 80 wanita, $93 \%$ diantaranya berhasil menunda persalinan $>48$ jam. Jumlah hari penundaan persalinan pada wanita yang bersalin pada 37 minggu pada magnesium sulfat yaitu $41 \%(16)$.

Nyeri persalinan sering dialami karena rangsangan nosiseptor dalam adneksa, uterus, dan ligamen pelvis. Nyeri persalinan terjadi akibat dilatasi seviks dan sagmen uterus bawah dengan distensi lanjut, peregangan, dan trauma pada serat otot dan ligamen. Faktor penyebab nyeri persalinan adalah :

a. Berkurangnya pasokan oksigen ke otot rahim (nyeri persalinan menjadi lebih hebat jika interval antara kontraksi singkat, sehingga pasokan oksigen ke otot rahim belum sepenuhnya pulih).

b. Meregangnya leher rahim (effacement dan pelebaran).

c. Tekanan bayi pada saraf di dan dekat leher rahim dan vagina.

d. Ketegangan dan meregangnya jaringan ikat pendukung rahim dan sendi panggul selama kontraksi dan turunnya bayi.

e. Tekanan pada saluran kemih, kandung kemih, dan anus.

f. Meregangnya otot-otot dasar panggul dan jaringan vagina.

g. Ketakutan dan kecemasan yang dapat menyebabkan dikeluarkannya hormon stress dalam jumlah besar (epinefrin, norepinefrin, dan lain-lain) yang mengakibatkan timbulnya nyeri persalinan yang lama dan lebih berat

Rasa nyeri pada persalinan terjadi karena kontraksi rahim dalam pengeluaran janin. Dalam persalinan normal, saat awal persalinan sampai pembukaan lengkap akan berlangsung 12- 
18 jam, dilanjutkan kala pengeluaran janin sampai pengeluaran plasenta. Rasa nyeri ini dipengaruhi oleh kelelahan, keletihan, kecemasan, dan rasa takut yang akan menyebabkan peningkatan rasa nyeri. Rasa nyeri muncul akibat respon psikis dan refleks fisik. Kualitas rasa nyeri fisik dinyatakan sebagai nyeri tusukan, terbakar, rasa sakit, denyutan, rasa mual, dan kram.

Munculnya nyeri sangat berkaitan erat dengan reseptor dan adanya rangsangan. Reseptor nyeri yang dimaksud adalah nociceptor, merupakan ujung-ujung saraf sangat bebas atau bahkan myelin yang tersebar pada kulit dan mukosa, khususnya pada organ persendian, dinding arteri, hati dan kandung empedu.

\section{KESIMPULAN}

Dari hasil penelitian dapat disimpulkan bahwa, Ancaman partus prematur dapat terjadi disebabkan oleh beberapa faktor, meliputi : usia ibu, gravidarum, tingkat pendidikan, riwayat abortus, dan riwayat partus premature. MgSO4 menjadi pilihan kedua sebagai tokolitik setelah nifedipin di RSUP Dr. Wahidin Sudirohusodo Makassar, RSUD Labuang Baji, RSIA Sitti Khadijah, dan Klinik Sitti Khadijah Makassar, dengan efektivitas sebesar $71.87 \%$ dalam mengurangi kontraksi dan menunda persalinan prematur ditandai dengan berkurangnya kontraksi dalam waktu $2 \times 24$ jam.

\section{DAFTAR PUSTAKA}

1. Claas, M.J., Bruinse, H.W., Van der Heide-Jalving, M., Termote, J., de Vries, L.S., 2010, Changes in survival and neonatal morbidity in infants with a birthweight of 750g or less. Neonatology. (98); pp. 278-88

2. Kugelman, A., Bader, D., Lerner-Geva, L., et al, 2012, Poor outcomes at discharge among extremely premature infants: a national populationbased study. Archives of Pediatrics \& Adolescent Medicine. (6); 543-50

3. Boyle, E., Poulsen, G., Field, D., Kurinczuk, et al, 2012, Effects of gestational age at birth on health outcomes at 3 and 5 years of age: Population based cohort. BMJ. (344); e896.

4. World Health Organization, 2015, On interventions to improve preterm birth outcomes. WHO Press. France. p1-98.

5. Muglia, L., Michael, K., 2010, The enigma of spontaneous preterm birth NEJM. (362); pp.529-35.

6. Yulifah, Yuswanto, 2009, Asuhan Kebidanan Komunitas, Salemba Medika, Jakarta. Hal.16-17.
7. Agustin, C., Romero, R., Pedro, J., 2011, Nifedipine for The Management of Preterm Labor. Am J Obstet Gynecol. Department of Obstetrics and Gynecology. Wayne State University, Detroit, MI.

8. Krisnadi, S.R., 2009, Faktor Risiko Persalinan Prematur. Refika Aditama. Bandung.

9. Ip, M., Peyman, E., Lohsoonthorn, V., Williams, M.A., 2010, A Case Control Study of Preterm Delivery Risk Factors According to Clinical Subtypes and Severity. J.Obstet.Gynaecol Res. 36(1); pp.1-16

10. Kartikasari, R.I., 2010, Hubungan Faktor Risiko Multiparitas Dengan Persalinan Preterm Di RSUD Dr. Soegiri Lamongan [serial on the internet], [cited 2017 july 27]; 1: [about 46 screens]. Available from : http://eprints.uns.ac.id/10350/1/154252108201011441.pdf

11. Agustiana, T., 2012, Faktor Faktor Yang Berhubungan Dengan Persalinan Prematur di Indonesia Tahun 2010 (Analisis RISKERDAS 2010). [serial on the internet], [cited 2017 juli 27]; 1: [about 127 screens]. Available from : $\quad$ http://lib.ui.ac.id/file?file=digital/20302750-S Tria\%20Agustiana.pdf

12. Suspimantari, C., Pramono, Besari, A., 2014, Faktor Risiko Prematuritas Yang Berpengaruh Terhadap Luaran Maternal Dan Perinatal Berdasarkan Usia Kehamilan Studi Kasus Di Rsup Dr. Kariadi Semarang Tahun 2013. Tesis FK UNDIP. Semarang.

13. Sulistiarini, D., 2016, Faktor - Faktor Yang Memengaruhi Kelahiran Prematur Di Indonesia: Analisis Data Riskesdas 2013. [serial on the internet], [cited 2017 july 27]; 1 [about 7 screens]. Available from: https://media.neliti.com/media/publications/36815-ID-faktor-faktoryang-memengaruhi-kelahiran-prematur-di-indonesia-analisis-dataris.pdf

14. Oroh, S, 2015, Karakteristik Persalinan Prematur Di Rsup Prof. Dr. R. D. Kandou Manado. [serial on the internet], [cited 2017 july 27]; 1: [about 3 screens]. Available from: https://ejournal.unsrat.ac.id/index.php/eclinic/article/view/8605/817 8

15. Kawagoe, Y., Sameshima, H., Ikenoue, T., 2010, Magnesium Sulfate as a Second-Line Tocolytic Agent for Preterm Labor: A Randomized Controlled Trial in Kyushu Island. Department of Obstetrics and Gynecology, National Hospital Organization Nagasaki Medical Center. Japan, [cited 2017 February 20]. Available from: https://www.hindawi.com/journals/jp/2011/965060/

16. Gde, T.A., 2014, Perbandingan Antara MgSO4 Dan Nifedipin Sebagai Tokolitik Pada Preterm Labor. [serial on the internet], [cited 2017 Juni 2]; 1 : [about 32 screens] Available from: https://fk.unud.ac.id/obgin/wp-

content/uploads/2015/04/Perbandingan_Antara_MgSO4_dan_Nifedipi n_sebagai_Tokolitik_pada_Preterm_Labor.pdf 